\title{
Secondary school teachers' learning: environments, specificities and considerations for educational practice
}

\author{
Maria Domingo-Coscollola \\ Universitat Internacional de Catalunya. Spain. \\ mdomingoc@uic.cat \\ Judit Onsès-Segarra \\ Universitat de Girona. Spain. \\ judit.onses@udg.edu \\ Juana M. Sancho-Gil \\ Universitat de Barcelona. Spain. \\ jmsancho@ub.edu
}

Received: $17 / 1 / 2021$

Accepted: 25/5/2021

Published: 31/1/2022

\begin{abstract}
This article is based on the research project APREN-DO aimed at exploring how secondary school teachers learn. Using an inclusive research approach and visual and narrative methods, we conducted the study with teachers rather than focusing on teachers. Twenty-eight secondary school teachers in the province of Barcelona (Spain) created their learning cartographies, showing what, how, where, with whom, and with what they learn. They then narrated their cartographies and discussed the notions of learning and educational practice in the 21 st century. This paper summarizes the results and conclusions about teachers' learning environments, specificities and considerations regarding their learning, and their thoughts about educational practices. Finally, we present and discuss teachers' reflections and proposals for redesigning educational practice taking into account the need to contemplate the different literacies and competences that exist in today's society, encouraging student participation based on their interests and particularities, providing a space for affections and emotions, and prioritizing the personalization of students' learning and the skill of learning to learn.
\end{abstract}

Keywords: teacher education; professional development; teacher training; learning cartographies; secondary school teachers

Resum. Aprenentatge del professorat de secundària: entorns, especificitats i consideracions per a la pràctica educativa

Aquest article es basa en el projecte de recerca APREN-DO, dirigit a explorar com aprenen els professors de secundària. Utilitzant un enfocament de recerca inclusiu i mètodes visuals i narratius, hem dut a terme l'estudi amb professors en lloc de centrar-nos en els professors. Vint-i-vuit professors d'ensenyament secundari de les comarques de Barcelona (Espanya) van crear les seves cartografies d'aprenentatge, en què van mostrar què, com, on i amb qui aprenen. Després van narrar les seves cartografies i van discutir les nocions d'aprenentatge i pràctica educativa al segle XxI. Aquest article resumeix els resultats i les conclusions sobre els entorns d'aprenentatge dels professors, les especificitats del seu aprenentatge i les seves 
consideracions sobre la pràctica educativa. Per finalitzar, presentem i discutim les reflexions i propostes del docents per redissenyar la pràctica educativa tenint en compte la necessitat de considerar les diferents alfabetitzacions i competències que existeixen a la societat actual, fomentar la participació dels estudiants en funció dels seus interessos i particularitats, proporcionar un espai per als afectes i les emocions i prioritzar la personalització de l'aprenentatge dels estudiants i la seva capacitat d'aprendre a aprendre.

Paraules clau: formació docent; desenvolupament professional; formació del professorat; cartografies d'aprenentatge; professorat de secundària

Resumen. Aprendizaje del profesorado de secundaria: entornos, especificidades y consideraciones para la práctica educativa

Este artículo se basa en el proyecto de investigación APREN-DO, cuyo objetivo es explorar cómo aprenden los profesores de secundaria. Utilizando un enfoque de investigación inclusivo y métodos visuales y narrativos, realizamos el estudio con los profesores en lugar de centrarnos en ellos. Veintiocho profesores de secundaria de la provincia de Barcelona (España) crearon sus cartografías de aprendizaje, en las que mostraron qué, cómo, dónde y con quién aprenden. Luego narraron sus cartografías y discutieron las nociones de aprendizaje y práctica educativa en el siglo xxi. Este artículo resume los resultados y las conclusiones sobre los entornos de aprendizaje de los docentes, las especificidades de su aprendizaje y sus consideraciones sobre la práctica educativa. Para finalizar, presentamos y discutimos las reflexiones y propuestas de los profesores para rediseñar la práctica educativa teniendo en cuenta la necesidad de considerar las distintas alfabetizaciones y competencias que existen en la sociedad actual, fomentar la participación de los estudiantes en función de sus intereses y particularidades, brindar un espacio para los afectos y las emociones, y priorizar la personalización del aprendizaje de los estudiantes y su capacidad de aprender a aprender.

Palabras clave: formación docente; desarrollo profesional; formación del profesorado; cartografías de aprendizaje; profesorado de secundaria

\author{
Summary \\ 1. Introduction 4. Discussion and conclusions \\ 2. Material and methods 5. Support \\ 3. Results Bibliographical references
}

\title{
1. Introduction
}

In today's rapidly changing society there is a wide and diverse range of possibilities for learning and professional development. In this new reality, teaching practice faces new challenges, and teachers play an important role as agents of change and innovation (Solheim et al., 2018). Therefore, their ways of learning, training, and professional development are crucial issues today.

There is a long tradition of studies on teachers' education and professional development (Admiraal et al., 2016; Bakkenes et al., 2010; Durksen et al., 2017; Fernández-de-Alava \& Quesada-Pallarés, 2017; García-Vera et al., 2020; Hardy et al., 2018; Korthagen, 2017; Kyndt et al., 2016; Opfer \& Ped- 
der, 2011; Powell \& Bodur, 2019; Souto-Seijo et al., 2020; Szelei et al., 2019, among others). However, we still lack greater insight into how today's teachers learn (Admiraal et al., 2016; Aharonian, 2019; Geeraerts et al., 2018; Kvam, 2019; Louws et al., 2017; Pintor \& Vizcarro, 2005; Quesada-Pallarés et al., 2017; Zhang \& Wong, 2019).

Nowadays, due to the diversification of learning systems and resources, the phenomenon of learning is considered more complex than ever and difficult to describe through mere causal explanations (Aharonian, 2019; Altan \& Lane, 2018; Mockler, 2020; Opfer \& Pedder, 2011; Phillips, 2014). According to Phillips (2014), learning is connected to people's lives, their complexities and contexts. And, although much learning can be assimilated unconsciously (Mlodinow, 2013), in-depth reflection can suggest "fruitful connections between practice, theory and person" (Korthagen, 2017, p. 398). In this sense, the insistence of Solheim et al. (2018, p. 533) that "scientific knowledge about how teachers learn and how teachers' learning can be improved is of utmost importance", takes on a profound relevance.

We also believe that we need to pay "greater attention... to how such learning comes about" (Hardy et al., 2018, p. 438). Understanding how today's teachers learn would help us to rethink teacher education and lifelong and lifewide learning in accordance with the requirements of today's society.

In response to this general context, we launched the educational research project APREN-DO: How Teachers Learn: Educational Implications and Challenges for Social Change. The general purpose of the project was to explore what, how, where, with whom, and with what secondary school teachers learn. More specifically, this article has three main purposes. Firstly, to describe the learning environments of secondary school teachers (inside and outside school). Secondly, to identify the specificities of teachers' learning, that is, what learning means to teachers and what conditions or elements make it possible. And, thirdly, to describe teachers' considerations of their educational practice. This implies considering teachers' reflections on their learning, ways of learning, and the extent to which all this influences their teaching practice. In short, our study seeks to shed light on teachers' awareness of their learning and the connections they draw between it and their classroom teaching.

As part of the fieldwork, the teachers participating in the project created and narrated learning cartographies (illustrating what, how, where, with whom, and with what they learn). It has been noted that cartographies and narrative practices can be used as part of teachers' self-knowledge and selflearning processes (Altan \& Lane, 2018; Amott, 2018; Fendler, 2013; Hernández-Hernández et al., 2018; Ulmer \& Koro-Ljungberg, 2015).

\section{Material and methods}

To conduct a complex, in-depth exploration of teacher learning, the research team adopted both a constructionist (Holstein \& Gubrium, 2008) and qualitative approach (Denzin \& Lincoln, 2012). Accordingly, we conducted a par- 
ticipatory and inclusive study (Nind, 2014). The methods employed in the project were observation, field notes and, as core procedures, teachers' learning cartographies, narratives, and considerations about learning (Altan \& Lane, 2018).

We used the cartographies as a research strategy that is increasingly employed in educational research (Atkinson, 2011; Braidotti, 2018; Hernández-Hernández et al., 2018; McKinnon, 2011; Ruitenberg, 2007; Ulmer \& Koro-Ljungberg, 2015). Our starting point was to "consider cartography as a powerful and versatile representation of personal/social learning trajectories [...] as well as an increaser of knowledge" (Hernández-Hernández et al., 2018, p. 108). Moreover, "using a blank cartography, a map without cardinal direction or points of reference, frees paths of analytical movement to travel in various new and unexpected directions in order to generate different knowings" (Ulmer \& Koro-Ljungberg, 2015, p. 149).

The fieldwork was carried out with groups of teachers from three secondary schools in towns in Barcelona province. The selection of participants was intentional (Patton, 2002), since the schools were selected based on the willingness of staff to reflect on their learning and improve their practice. The fieldwork with these three groups took place at the participants' schools. A fourth participating group was composed of three teachers from different state secondary schools in the city of Barcelona. With this group, the fieldwork was conducted at the Fine Arts Faculty of the University of Barcelona. In total, 29 teachers with different profiles were involved, of whom 28 created and narrated their learning cartographies (see Table 1).

Table 1. Participants in the research and their productions

\begin{tabular}{lcccc}
\hline $\begin{array}{c}\text { Groups of secondary } \\
\text { school teachers }\end{array}$ & $\begin{array}{c}\text { Number of } \\
\text { teachers }\end{array}$ & $\begin{array}{c}\text { Gender } \\
\end{array}$ & $\begin{array}{c}\text { Experience } \\
\star \star\end{array}$ & $\begin{array}{c}\text { Cartographies } \\
\text { and narratives } \\
\text { produced }\end{array}$ \\
\hline Secondary school $1(\mathrm{~S} 1)$ & 11 & $2 \mathrm{M}-9 \mathrm{~F}$ & $2 \mathrm{~S}-3 \mathrm{M}-6 \mathrm{~L}$ & 10 \\
\hline Secondary school 2 (S2) & 8 & $2 \mathrm{M}-6 \mathrm{~F}$ & $2 \mathrm{~S}-5 \mathrm{M}-1 \mathrm{~L}$ & 8 \\
\hline Secondary school 3 (S3) & 7 & $1 \mathrm{M}-6 \mathrm{~F}$ & $2 \mathrm{~S}-2 \mathrm{M}-3 \mathrm{~L}$ & 7 \\
\hline Mixed group (MG) & 3 & $3 \mathrm{~F}$ & $1 \mathrm{M}-2 \mathrm{~L}$ & 3 \\
Total & 29 & $5 \mathrm{M}-24 \mathrm{~F}$ & $6 \mathrm{~S}-11 \mathrm{M}-12 \mathrm{~L}$ & 28 \\
\hline
\end{tabular}

${ }^{*}$ Gender: M=Male / F=Female

${ }^{* *}$ Years of experience: $\mathrm{S}=$ short career (less than 5 years' teaching experience); $\mathrm{M}=$ =medium career ( 5 to 15 years); L=long career (more than 15 years)

Source: ESBRINA research group.

Before starting the fieldwork, the participants were informed about the project and the activities involved, and all signed an ethical form volunteering to participate in the research. The fieldwork consisted of two meetings at which the same methodological procedure was adopted for all four groups of teachers. The researchers took part in both meetings, taking photographs, 
guiding and assisting the teachers, filming the meetings on video, and/or taking field notes. The first meeting was intended to create an environment of trust and to produce the learning cartographies. During the process of creating the cartographies, the researchers suggested ideas to answer the questions raised and helped the teachers to resolve the challenge. Specifically, these clues were: what, how, where, with whom, and with what they learn inside and outside the school; what their present and/or past learning scenarios are; what learning means to them; and when they think they learn or have learned. Thanks to this exchange, a relationship based on listening and providing support grew between the researchers and the teachers over the course of the process. Consequently, our task consisted of listening and/or providing feedback based on what each teacher suggested (Figure 1).

Figure 1. Photographs of the first meeting

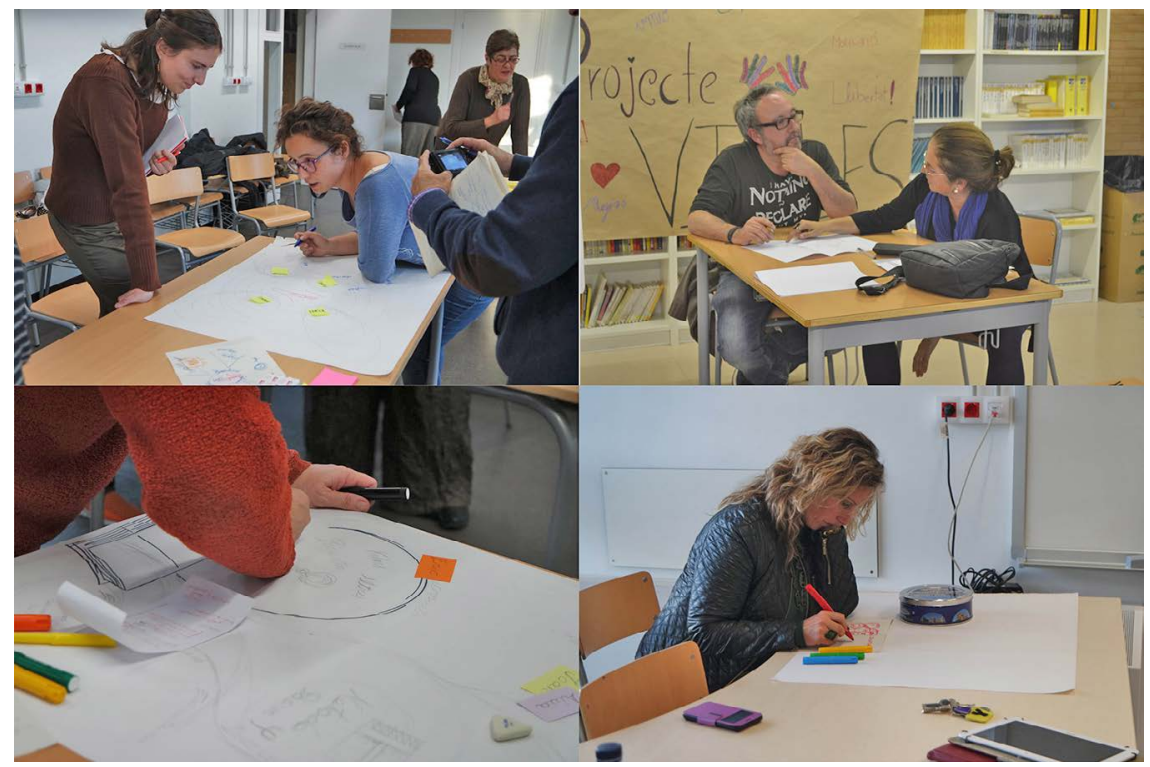

Source: ESBRINA research group.

In making their cartographies, most teachers used different materials, whether supplied by the research team or brought by them (photographs, paper, stickers, pencil drawings, etc.). Once they had completed them, all the teachers were filmed on video narrating their cartographies. The content of the 28 teachers' narratives was then transcribed and the narratives were examined using thematic analysis (Boyatzis, 1998; Braun \& Clarke, 2006). According to Nowell et al. $(2017$, p. 2), thematic analysis is "a useful method for examining the perspectives of different research participants, highlighting 
similarities and differences, and generating unanticipated insights". The procedure is also useful for summarizing key features.

The researchers conducted data analysis manually. Using the data gathered at the first meeting, they established two main themes: teachers' learning environments (our first aim); and the specificities of teachers' learning (our second aim). The first theme contained three sub-themes: learning environments inside school; learning environments outside school; and learning environments between those two spheres. Five sub-themes emerged from the second theme: specificities related to the importance of experience in learning; to relations with others; to the connections between different learning environments; to the importance of action and performance in learning; and, finally, to affects and emotions.

Later, we organized a second meeting with each of the four groups of teachers. The purpose of this meeting was to give them feedback on their cartographies and to establish a dialogue concerning their learning processes and scenarios and their considerations regarding ways of teaching and learning. Their reflections on learning and teaching practice were also discussed. All the content of the second meeting was recorded, transcribed, and analysed. In this way, also through thematic analysis, we identified teachers' considerations of their educational practice (our third aim). In total, fifteen researchers were involved in the field study and data analysis of each group of teachers.

\section{Results}

In total, 28 teachers created and narrated their learning cartographies (Figure 2) and shared their considerations and reflections on learning and educational practice. The findings were organized according to our three aims. Accordingly, we focused our outcomes on:

- Teachers' learning environments.

- Specificities of teachers' learning.

- Considerations of teachers' educational practice.

\subsection{Teachers' learning environments}

In this section, we present the learning environments described by the participating teachers. In doing so, we draw on the teachers' cartographies and narratives presented at the first meeting.

Teachers' learning takes place not only in formal and institutional contexts, but also throughout life in different contexts. We identified these significant learning environments by highlighting where, with whom, and with what teachers learn. 
Figure 2. Examples of the teachers' cartographies

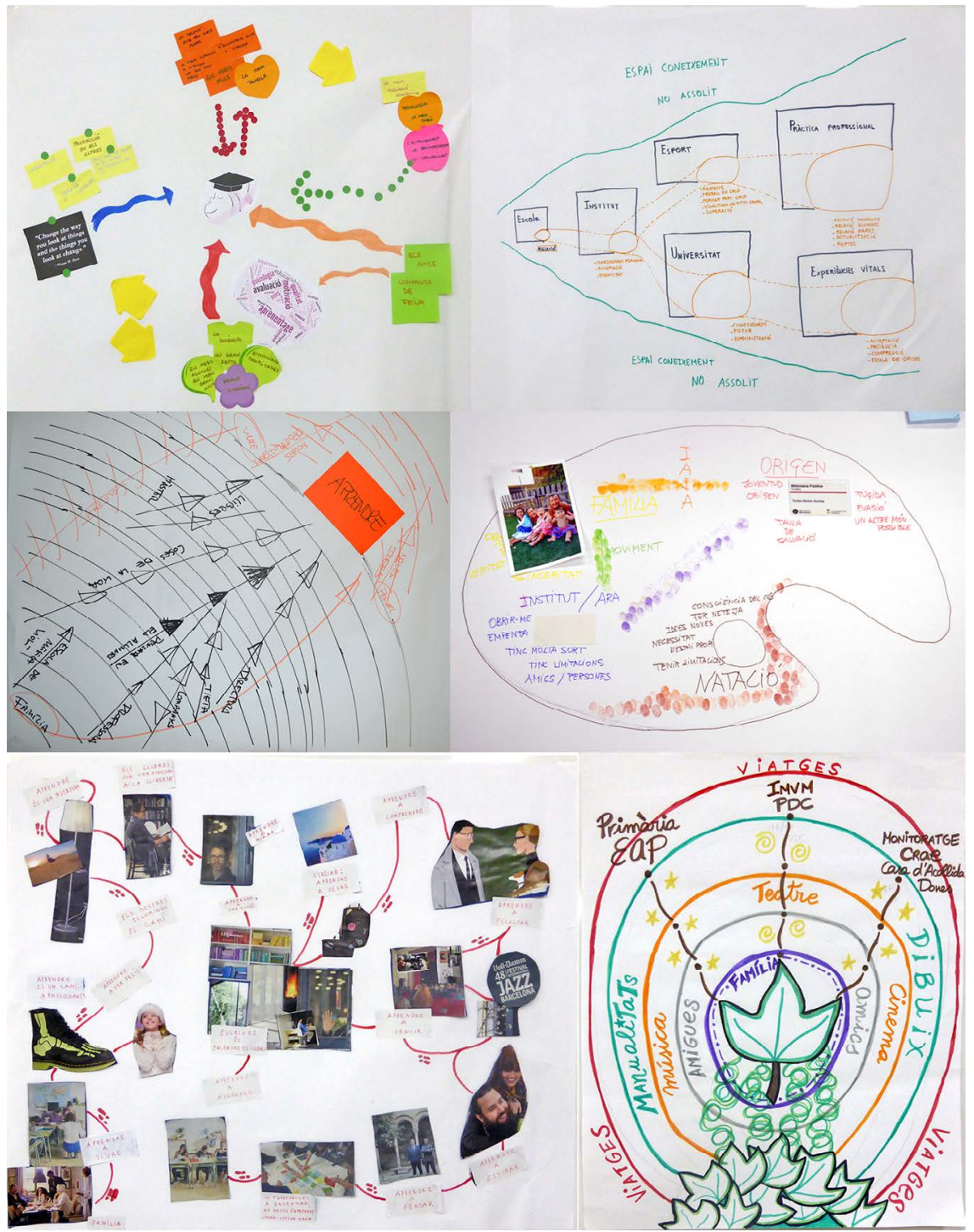

Source: ESBRINA research group.

\subsubsection{Inside school}

At school as students (when they were young) and now as teachers, they have learned from teachers, from other students, and from teaching and learning processes and practices: "at school, surrounded by friends and cultural references that make you want to learn and love learning" (Teacher-7, S3); "from 
the opinions of other teachers" (Teacher-3, MG); "I am nourished by the students and they help me to improve" (Teacher-1, S2); "the students [...] their doubts and concerns, force me to study" (Teacher-2, S3).

\subsubsection{Outside school}

The family plays an important role in learning, both when teachers were children and now as parents themselves: "my brother taught me to speak [...] patience, confidence" (Teacher-6, S2); "my mother always bought us books to read" (Teacher-5, S3); "I learn from my family, my children and my husband" (Teacher-2, S2); "how and what my children learn leads me to think" (Teacher-7, S3).

In social environments with friends, they learn by doing, especially from relationships, attitudes, and conversations: "another area of learning is personal relationships with friends" (Teacher-8, S1); "friends have influenced the way I have become a person" (Teacher-2, S3).

In cultural contexts, they learn through activities at museums, cinemas, theatres, and libraries, at concerts, and by travelling: "travelling teaches a way of looking at the world, learning by living" (Teacher-7, S1); "cinema, social relations, reading, observing the world of art, reflection, philosophy" (Teacher-4, S1); "reading an article, going to the theatre, seeing a film" (Teacher-7, S3).

In sports environments, they learn by doing activities like gymnastics, yoga, reiki, swimming, and mountaineering: "Yoga and reiki were fundamental" (Teacher-6, S2); "swimming served me as a nexus to link up with other concepts" (Teacher-4, S2); "the gym" (Teacher-9, S1); "the mountains and sports, which also give me satisfaction, feedback, excitement, and challenges" (Teacher-3, S1).

In everyday settings, they learn by undertaking routine activities such as going to the market, participating in projects, volunteering, or watching television: "I learn in any situation, for example, from conversations at the marketplace" (Teacher-5, S2); "environments that were not in principle designed for learning" (Teacher-2, S2); "the other learning space is everyday activities" (Teacher-2, S2); "television series, because they help me to form myself" (Teacher-6, $\mathrm{S} 1)$; "as a monitor at a centre of educational care residences" (Teacher-2, S1).

\subsubsection{Inside and outside school}

Finally, Internet is another important and valuable source of learning, both inside and outside school. This is an "in-between" learning context since it connects both inside- and outside-school environments. Internet enables selfeducation and learning (e.g., by taking courses, participating in networks, or watching series): "Internet is my most important learning environment" (Teacher-2, S2); "Internet is a very valuable source of learning [...] I research, search and maybe I don't attend courses, but I read an article and incorporate it into my classes" (Teacher-1, S3). 


\subsection{Specificities of teachers' learning}

In this section, we outline certain characterizations of teachers' learning and identify the most significant features. In doing so, we also draw on the teachers' cartographies and narratives.

\subsubsection{Experience}

When teachers attach meaning to their learning, they basically relate it to the importance of their experiences. They highlight the experience of being a boy, a girl, or a student, their own experience as professional teachers and as adults in families: "the experiences of my childhood helped me" (Teacher-1, S2); "the experience of being able to teach a language" (Teacher-7, S1); "the experiences that my classmates had in the classroom and my own teaching experience" (Teacher-1, S3).

\subsubsection{Relations}

Learning experiences are profoundly mediated by relationships, especially those of a more horizontal nature, such as interaction, collaboration, exchange, and listening: "in my important learning settings there is exchange, difference, listening, and collaboration" (Teacher-8, S1); "knowledge is established in collaboration" (Teacher-6, S2); "I need others in order to learn with them" (Teacher-4, S1); "listening to everything and everyone" (Teacher-2, MG).

\subsubsection{Connections}

In learning processes there is a removal of physical and temporal barriers, as well as boundaries between formal and informal settings. Learning implies interrelation and interconnectedness: "My learning process is continuous" (Teacher-5, S2); "I am always learning, I like to think that I will learn all my life" (Teacher-1, S3); "the sea is something infinite that never ends, the same as learning in any space and time" (Teacher-8, S1); "a mixture of learning inside and outside the education system" (Teacher-6, S2); "from all actors from all environments" (Teacher-1, MG).

\subsubsection{Performance}

Learning comes mainly during the performance of actions (such as sharing, collaborating, observing, reading, writing, drawing, looking, talking, researching, reflecting, analysing, evaluating, teaching, experimenting, and listening): "sharing ideas, the experiences of my peers and my own" (Teacher-1, S3); "social relations, reading, observation of the world of art, reflection, and experimentation" (Teacher-4, S1); "becoming aware of connections and learning processes!” (Teacher-5, S2).

\subsubsection{Emotions and affects}

Emotions and affections are present in and influence the learning process. For example, they can generate curiosity, the joy of learning, tranquillity, reflec- 
tion, effort, humour, well-being, peace, and tension: "the main driver of learning is emotion: without it there is no learning" (Teacher-7, S2); "my learning is like a path that is guided above all by emotion and curiosity" (Teacher-8, S1); "I learn when I feel comfortable, when I am enjoying myself" (Teacher-7, S1); "one learns with movement but also with tranquillity and reflection" (Teacher-7, S1); "humour as a tool for learning" (Teacher-8, S1).

\subsection{Considerations of teachers' educational practice}

This section addresses the main considerations about teachers' learning and educational practice that were suggested at the second workshop meeting. At this meeting, they discussed the learning process itself, the learning of other teachers, and their students' learning, in addition to identifying and exploring the influences of life experiences on their learning and educational practices. At this point, the teachers highlighted the importance of a pedagogical rethink of educational practice to bring it closer to the way people learn today. Below are the most significant considerations.

If teachers think about outside-school contexts as learning environments, they also need to attach importance to students' informal and non-formal learning experiences. The teachers also recognized that today's society offers students new and different learning experiences outside educational institutions.

Making a cartography of their learning led teachers to: 1) become aware of the importance of introducing literacy skills other than text-based competences. The teachers stressed that the educational institution is still deeply textualized. They noted that, in today's society, other literacies, such as visual, oral and audio-visual, and digital and auditory literacies, are increasingly visible and important; 2 ) the need for more spaces to develop creative, collaborative, and inquiry processes. In this regard, they noted the importance of creating an environment of trust where not knowing can be a source of learning, and of proposing challenges or questions that do not have more or less preestablished answers.

Their participation in research offered teachers a space for reflection that is sometimes unavailable at school. As a result, they appreciate the importance of allocating more time to tasks of pedagogical value in teaching practice. In this regard, the teachers noted the prevailing trend of continuing to apply the same curriculum, at the same time and at the same pace for all students, using the same assessment methods. They also recognized the importance of rethinking student assessment because memorization and repetition still predominate.

Teachers valued the appropriateness of child-centred approaches and personalized learning and the importance of recognizing and accepting their students' capacity to make their own decisions about their learning processes. They also highlighted the importance of increasing levels of confidence in students' autonomy and in their ability to self-manage their learning.

At this second meeting, the teachers explored the idea of reflection as a basis for learning. At a general level, teachers stressed that their knowledge and 
self-knowledge had increased. Therefore, for them, their participation in this research was a positive professional development experience.

\section{Discussion and conclusions}

A metamorphosis is taking place in the way teachers learn today. We observe that teachers' learning takes place in different contexts and across the lifespan, in different places and times, and with different people and resources. Thus, in line with other studies, such as Sangrà et al. (2019), our results show that teachers are already aware or are becoming aware that, in addition to institutional or formal environments, they also learn in non-formal and informal settings and that they do this through multimodal texts and a diversified set of experiences.

Our study confirms that "teachers can benefit intensely by engaging in extracurricular activities in areas of interest" (Aharonian, 2019, p. 13). Here, we go beyond the contributions of traditional research, which highlights only formal and institutional learning contexts. In fact, teachers referred very little or not at all to their initial and in-service professional development experiences. Therefore, professional learning not only takes place during initial and in-service teacher education in institutional settings but is a continuous learning process.

This research, along with other studies (Hernández-Hernández et al., 2018; Sancho-Gil, 2011; Sancho-Gil \& Hernández-Hernández, 2014; Sangrà et al., 2019; Souto-Seijo et al., 2020), also shows that teacher learning arises from experiences lived over time and in different environments. All of these experiences have an impact not only on teacher learning but also on teachers' practice. In this same vein, as Altan and Lane (2018, p. 238) noted, "teachers' significant life experiences and dispositions influence teaching practice". Another relevant outcome of this research concerns the importance of affects, emotions, and relationships with others in learning processes.

Our research further confirms the idea that "teachers' reflections on their practice [are] a vehicle for learning" and that "teachers' stories [are] key resources for teacher education programmes" (Hardy et al., 2018, p. 435). We can agree that "teachers' actions, talk and ongoing relations can serve as a vehicle for transforming their learning" (Hardy et al., 2018, p. 421) and that "when teachers work and learn together, opportunities for profound learning arise" (Solheim et al., 2018, p. 530).

The teachers stressed the problem that, in educational practice, the predominant trend is still to implement the same curriculum, at the same time and at the same pace for all students, and with the same assessment methods. They also put forward reflections and proposals to rethink educational practice. Based on our research, and building on our dialogue with teachers, we can suggest significant educational considerations to guide educational practice: 
- Teachers noted the importance of creative, collaborative, and researchbased educational initiatives that address real and vital problems facing today's society. This rethink could lead to the transformation of the teaching-learning culture of educational institutions, enabling them to become meaningful learning organizations in today's society (Domingo-Coscollola et al., 2018; Miño-Puigcercós et al., 2019). However, we also recognize that there are various tensions that make it difficult to implement this kind of practice.

- The need to provide a space for affection and emotions in educational activities. The cognitive usually prevails in educational institutions. However, in practice, students' affective and emotional predisposition towards learning is an indispensable facilitator and conditioner for learning (Korthagen, 2017).

- The desirability to prioritize the personalization of students' learning and ability of learning to learn. The personalization of learning implies recognizing "the assumption of control on the part of the student, taking into account his or her voice and recognizing his or her capacity to make decisions in and about the learning process itself" (Coll, 2016, p. 53). To this end, the role of the teacher is fundamental. In practice, "there is a parallel between teachers' learning and students' learning" (Solheim et al., 2018, p. 531). For example, "teachers with an inherent commitment to life-long learning sow the seeds for their students to become life-long learners" (Durksen et al., 2017, p. 59).

- The benefits of taking into account different literacies (textual, visual, digital, audio-visual, verbal, and aural) and competences in today's society. In this respect, Guzmán-Simón et al. (2017, p. 202) pointed out that there is "a wide gap between the digital competence developed in informal learning contexts and its scarcity in university literacy practices". For example, with a view to reducing this gap, mastery of digital competence plays an increasingly important role in the teaching profession.

- The need to encourage student participation based on their interests and particularities. For example, we highlight the need to consider (during formative processes) the background, trajectories, and experiences of students outside the institution. In this way, as Altan and Lane (2018, p. 246) noted, "elements of certain constructive life experiences [...] contribute to effective teaching dispositions".

- The importance of taking into account students' knowledge and experience and the existence of different cultural codes. Thinking that everyone, regardless of their socio-cultural, linguistic, and economic background, should understand the "code" of the school, the teaching materials, their classmates, and their teachers in the same way, may be the beginning of a misunderstanding that leads to disengagement and school failure.

The participating teachers were aware that all these reflections and needs imply challenges and tensions that should be addressed by the education sys- 
tem as a whole, from policy development to initial and in-service teacher education programmes, school conditions and neighbourhood cultures.

One limitation to this study is that it was not possible to include and examine all dimensions of the subject matter, given its complexity and the short duration of the project. Our study is, therefore, partial and contingent. It is partial because the sample used was limited to a particular territory and profile of secondary schools and restricted in the literature considered. Moreover, it is contingent in that, as a complex subject, teacher learning is transitory and ever-changing.

However, our project's value resides in its consideration of little-studied dimensions of teacher learning. It also paves the way for new research to be designed with a view to exploring the complex analogical and digital worlds in which knowledge and learning are constructed in today's society. Based on this study, we would like to urge further exploration of the ways teachers learn, taking into account all the different contexts, times, resources, and people.

Finally, we should note that various studies show that teachers' considerations and reflections are not always transferred to their educational practice. As Vermunt (2014, cited in Solheim et al., 2018, p. 531) argued, "the transition from learning to practice is not simply learning new skills but fundamentally changing the mindset". However, we are confident that, little by little, teachers' growing understanding of their own learning processes will positively influence their professional practice. We also hope that the teachers who took part in this research and those who read this paper will become engaged and begin to act as agents of change in their schools. In doing so, we hope that they will strengthen their teaching professionalism and encourage the real and meaningful learning of their students through critical reflection.

\section{Support}

- Project partially funded by the Spanish Ministry of Economy, Industry and Competitiveness (EDU2015-70912-C2-1-R).

- ESBRINA Research group. Contemporary Subjectivities, Visualities and Learning Environments (2017SGR 1248). <http://esbrina.eu>

- REUNI+D Network of excellence. University Network for Research and Educational Innovation (RED2018-102439-T). <http://reunid.eu>

\section{Bibliographical references}

Admiraal, W., Kruiter, J., Lockhorst, D., Schenke, W., Sligte, H., Smit, B., TigelaAR, D., \& DE WIT, W. (2016). Affordances of teacher professional learning in secondary schools. Studies in Continuing Education, 38(3), 281-298. <https://doi.org/10.1080/0158037X.2015.1114469>

Aharonian, N. (2019). Making it count: Teacher learning in liminal spaces. Professional Development in Education, 1-17. <https://doi.org/10.1080/19415257.2019.1667413> 
Altan, S., \& Lane, J. F. (2018). Teachers' narratives: A source for exploring the influences of teachers' significant life experiences on their dispositions and teaching practices. Teaching and Teacher Education, 74, 238-248.

<https://doi.org/10.1016/j.tate.2018.05.012>

Амотт, P. (2018). Identification - a process of self-knowing realised within narrative practices for teacher educators during times of transition. Professional Development in Education, 44(4), 476-491.

<https://doi.org/10.1080/19415257.2017.1381638>

Atkinson, D. (2011). Art, equality and learning: Pedagogies against the state. Rotterdam: Sense Publishers. <https://doi.org/10.1007/978-94-6091-454-6>

Bakkenes, I., Vermunt, J. D., \& Wubbels, T. (2010). Teacher learning in the context of educational innovation: Learning activities and learning outcomes of experienced teachers. Learning and Instruction, 20, 533-548. <https://doi.org/10.1016/j.learninstruc.2009.09.001>

Boyatzis, R. (1998). Transforming qualitative information: Thematic analysis and code development. Thousand Oaks, CA: Sage.

BraidotTi, R. (2018). A theoretical framework for the critical posthumanities. Theory, Culture \& Society, in press, 1-13. <https://doi.org/10.1177/0263276418771486>

Braun, V., \& Clarke, V. (2006). Using thematic analysis in psychology. Qualitative Research in Psychology, 3, 77-101. <https://doi.org/10.1191/1478088706qp063oa>

Coll, C. (2016). La personalització de l'aprenentatge escolar: un repte indefugible. In J. M. Vilalta (Dir.). Reptes de l'educació a Catalunya. Anuari d'educació 2015 (pp. 43-104). Barcelona: Fundació Jaume Bofill.

Denzin, N., \& Lincoln, I. (2012). Manual de investigación cualitativa. Barcelona: Gedisa.

Domingo-Coscollola, M., Onsès, J., \& SAncho-Gil, J. M. (2018). La cultura DIY en educación primaria. Aprendizaje transdisciplinar, colaborativo y compartido en un Hub. Revista de Investigación Educativa, 36(2), 491-508. <https://doi.org/10.6018/rie.36.2.304421>

Durksen, T. L., Klassen, R. M., \& Daniels, L. M. (2017). Motivation and collaboration: the keys to a developmental framework for teachers' professional learning. Teaching and Teacher Education, 67, 53-66. <https://doi.org/10.1016/j.tate.2017.05.011>

Fendler, R. (2013). Becoming-Learner. Coordinates for mapping the space and subject of nomadic pedagogy. Qualitative Inquiry, 19(10), 786-793.

Fernández-de-Alava, M., \& Quesada-Pallarés, C. (2017). Estrategias de aprendizaje del profesorado europeo: género y etapa educativa. Bordón, 69(1), 67-81. <https://doi.org/10.13042/Bordon.2016.38597>

García-Vera, A. B., Rayón, L., \& De la Heras, A. M. (2020). Use of photo-elicitation to evoke and solve dilemmas that prompt changes to primary school teachers' visions. Journal of New Approaches in Educational Research, 9(1), 137-152. <https://doi.org/10.7821/naer.2020.1.499>

Geeraerts, K., TynjäLä, P., \& Heikkinen, H. L. T. (2018). Inter-generational learning of teachers: What and how do teachers learn from older and younger colleagues? European Journal of Teacher Education, 41(4), 479-495. <https://doi.org/10.1080/02619768.2018.1448781> 
Guzmán-Simón, F., García-Jiménez, E., \& López-Cobo, I. (2017). Undergraduate students' perspectives on digital competence and academic literacy in a Spanish university. Computers in Human Behavior, 74, 196-204. <https://doi.org/10.1016/j.chb.2017.04.040>

Hardy, I., Rönnerman, K., \& Edwards-Groves, C. (2018). Transforming professional learning: Educational action research in practice. European Educational Research Journal, 17(3), 421-441. <https://doi.org/10.1177/1474904117690409>

Hernández-Hernández, F., Sancho-Gil, J. M., \& Domingo-Coscollola, M. (2018). Cartographies as spaces of inquiry to explore teachers' nomadic learning trajectories. Digital Education Review, 33, 105-119.

Holstein, J. A., \& Gubrium, J. F. (2008). Handbook of constructionist research. New York: The Guilford Press.

Korthagen, F. (2017). Inconvenient truths about teacher learning: Towards professional development 3.0. Teachers and Teaching: Theory and Practice, 23(4), 387405. <https://doi.org/10.1080/13540602.2016.1211523>

Kvam, E. K. (2019). Untapped learning potential? A study of teachers' conversations with colleagues in primary schools in Norway. Cambridge Journal of Education, 48(6), 697-714. <https://doi.org/10.1080/0305764X.2017.1418833>

Kyndt, E., Gijbels, D., Grosemans, I., \& Donche, V. (2016). Teachers' everyday professional development: Mapping informal learning activities, antecedents, and learning outcomes. Review of Educational Research, 86(4), 1111-1150. <https://doi.org/10.3102/0034654315627864>

Louws, M. L., Meirink, J. A., Van Veen, K., \& Van Driel, J. H. (2017). Teachers' self-directed learning and teaching experience: What, how, and why teachers want to learn. Teaching and Teacher Education, 66, 171-183. <https://doi.org/10.1016/j.tate.2017.04.004>

McKinnon, I. (2011). Expanding cartographic practices in the social. In E. MargoLis \& L. Pauwels (Eds.). The Sage Handbook of Visual Methods (pp. 452-473). London: Sage Publications Ltd.

Miño-Puigcercós, R., Domingo-Coscollola, M., \& Sancho-Gil, J. M. (2019). Transforming the teaching and learning culture in higher education from a DIY perspective. Educación $X X 1,22(1), 139-160$. <https://doi.org/10.5944/educxx1.20057>

Mlodinow, L. (2013). Subliminal: cómo tu inconsciente gobierna tu mente. Barcelona: Crítica.

Mockler, N. (2020). Teacher professional learning under audit: Reconfiguring practice in an age of standards. Professional Development in Education, 1-15. <https://doi.org/10.1080/19415257.2020.1720779>

Nind, M. (2014). What is inclusive search? London: Bloomsbury Publishing.

Nowell, L. S., Norris, J. M., White, D. E., \& Moules, N. J. (2017). Thematic analysis: Striving to meet the trustworthiness criteria. International Journal of Qualitative Methods, 16, 1-13. <https://doi.org/10.1177/1609406917733847>

Opfer, V. D., \& Pedder, D. (2011). Conceptualizing teacher professional learning. Review of Educational Research, 81(3), 376-407. <https://doi.org/10.3102/0034654311413609> 
Patton, M. Q. (2002). Qualitative research and evaluation methods. London: Sage.

Phillips, D. C. (2014). Research in the hard sciences, and in very hard "softer" domains. Educational Researcher, 43(1), 9-11. <https://doi.org/10.3102/0013189X13520293>

Pintor, M., \& Vizcarro, C. (2005). Cómo aprenden los profesores. Un estudio empírico basado en entrevistas. Revista Complutense de Educación, 16(2), 623-644.

Powell, C. G., \& Bodur, Y. (2019). Teachers' perceptions of an online professional development experience: implications for a design and implementation framework. Teaching and Teacher Education, 77, 19-30. <https://doi.org/10.1016/j.tate.2018.09.004>

Quesada-Pallarés, C., Fernández-de-Álava, M., \& Gairín, J. (2017). ¿Cómo aprende el profesorado universitario español? Comprendiendo el uso de estrategias de aprendizaje. Revista de educación, 376, 135-162.

<http://doi.org/10.4438/1988-592X-RE-2017-376-347>

Ruitenberg, C. W. (2007). Here be dragons: Exploring cartography in educational theory and research. Complicity: An International Journal of Complexity and Education, 4(1), 7-24.

<https://doi.org/10.29173/cmplct8758>

SANCHO-GIL, J. M. (Coord.). (2011). Con voz propia. Los cambios sociales y profesionales desde la experiencia de los docentes. Barcelona: Octaedro. Recuperado de $<$ https://bit.ly/2W229y6>.

Sancho-Gil, J. M., \& Hernández-Hernández, F. (Coords.) (2014). Maestros al vaivén. Aprender a ser docente en el mundo actual. Barcelona: Octaedro.

Sangrà, A., Estévez, I., Iglesias, V., \& Souto-Seijo, A. (2019). Desarrollo profesional docente a través de las ecologías de aprendizaje: perspectivas del profesorado. Edutec. Revista Electrónica de Tecnología Educativa, 68, 42-53. <https://doi.org/10.21556/edutec.2019.68.1307>

Solheim, K., Ertesvåg, S. K., \& Berg, G. D. (2018). How teachers can improve their classroom interaction with students: new findings from teachers themselves. Journal of Educational Change, 19(4), 511-538. <https://doi.org/10.1007/s10833-018-9333-4>

Souto-Seijo, A., Estévez, I., Iglesias Fustes, V., \& González-Sanmamed, M. (2020). Entre lo formal y lo no formal: un análisis desde la formación permanente del profesorado. Educar, 56(1) 91-107. <https://doi.org/10.5565/rev/educar.1095>

Szelei, N., Tinoca, T., \& Pinho, A. S. (2019). Professional development for cultural diversity: the challenges of teacher learning in context. Professional Development in Education, 1-17. <https://doi.org/10.1080/19415257.2019.1642233>

Ulmer, J. B., \& Koro-Ljungberg, M. (2015). Writing visually through (methodological) events and cartography. Qualitative Inquiry, 21(2), 138-152. <https://doi.org/10.1177/1077800414542706>

Zhang, X., \& Wong, J. L. N. (2019). How do teachers learn together? A study of school-based teacher learning in China from the perspective of organisational learning. Teachers and Teaching: Theory and Practice, 24(2), 119-134. <https://doi.org/10.1080/13540602.2017.1388227> 